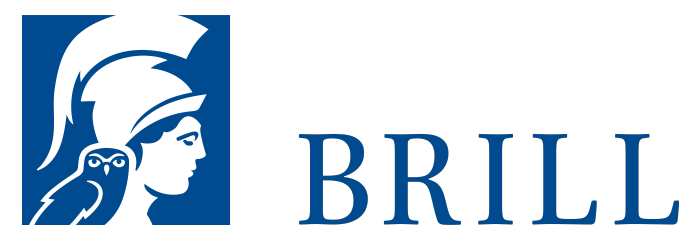

\title{
Prinzipien in der Ethik
}

\section{Author:Jan Gertken}

Wer an Moral denkt, denkt zumeist auch an Prinzipien. Denn nicht nur in der philosophischen Ethik, sondern auch im Alltag gelten Prinzipien vielen als unverzichtbarer Bestandteil des Versuchs, zu gerechtfertigten Antworten auf moralische Fragen zu gelangen. Ethische Partikularisten hingegen bestreiten, dass Prinzipien für moralisches Urteilen und Handeln von zentraler Bedeutung sind, und sie empfehlen, auf die Orientierung an kontextübergreifenden moralischen Richtlinien zu verzichten. In diesem Buch werden zentrale Positionen und Argumente aus der neueren Partikularismusdebatte systematisch verortet und diskutiert, um so das Potential prinzipienkritischer Entwürfe auszuloten. Hierbei zeigt sich: Prinzipien sind kein notwendiger, aber zumindest manchmal ein geeigneter Bezugspunkt im moralischen Urteilen und Handeln. Der Annahme, dass es möglich ist, sich in allen Entscheidungen an inhaltlich angemessenen Prinzipien zu orientieren, ist jedoch mit Skepsis zu begegnen.

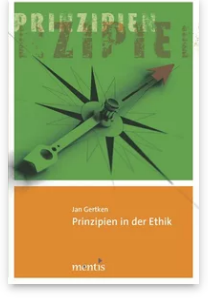

Pages: 439

Seiten

Language:

German

Subjects:

General,

Philosophy

Publisher: Brill | mentis

E-Book (PDF)

Released online: 15 Mar 2014

ISBN: 978-389785-980-7 List price

Paperback

Publication date: 15 Mar 2014 ISBN: 978-3$89785^{-832-9}$ List price 
For more information see brill.com

Order information: Order online at brill.com +44330 333 0049 | customerservices@brill.com Submission information: brill.com/authors

Titles published by Brill | Fink, Brill | mentis or Brill | Schöningh: +49(o)715413279216| brill@brocom.de 